\title{
The Debate on Globalization and International Revital- ization of Labor. A Critical Review
}

I Daniel Fleming'

Emeritus Associate Professor, Department of Society and Globalisation, International Development Studies, Roskilde University, Denmark

\section{Henrik Søborg ${ }^{2}$}

Associate Professor, Department of Society and Globalisation, International Development Studies, Roskilde University, Denmark

\begin{abstract}
This article discusses some alternative or critical theoretical contributions regarding globalization and labor. The main question in this discussion is if there are changes in direction of a possible revitalization of labor movements and if international solidarity can increase due to globalization. This question also relates to discussions of changes in division of work, the concept of work, working class, commodification, decommodification, and new centers of global production-all related to different paradigms or new concepts. The reason or need for reconceptualizing comes from the great transformation of capitalism in forms of neoliberal globalization, in a different direction than predicted by Polanyi. That is, instead of increased public sector decommodification (not profit- or market-oriented production) and national regulation, embedding capitalist markets, as seen after 1945, the last three decades have witnessed a countertransformation and large-scale recommodification by privatizing, disembedding, and deregulating global markets. As a consequence, inequality in income and working life conditions has increased in most countries and been used to press trade unions. Western industrial unions have been declining as many industries and labor-intensive, low-paid jobs moved to developing countries. Most blue-collar jobs are now in Asia, especially China, with about one-third of its employment blue collars. Is the center of global capital-labor contradictions and dynamics moving to the South, with a possibility of a new revitalization of labor and international solidarity? We discuss different optimistic and pessimistic views on a possible international revitalization of labor.
\end{abstract}

\section{KEY WORDS}

Revitalization of labor / working class concept / commodification / decommodification / occupational citizenship / precariat / knowledge workers / skill capture

\section{Introduction}

he mainstream globalization paradigm is a success story with the description of a growing middle class as the dynamic consumer and democracy engine of open market economies. In IMF and World Bank reports, often setting the global perspectives for media and popular understanding, the concept of working class is often included in or substituted by the middle class, which is growing in number and wealth,

\footnotetext{
${ }^{1}$ E-mail: fleming@ruc.dk

22 E-mail: henriks@ruc.dk
} 
and, the very poor, who are a decreasing part of the population due to free trade and free flow of capital and investments in the South. Job creation and growth come from the private sector according to the World Development Report on Jobs (World Bank 2013). Although labor's share of income compared to capital (total salary employment to Gross National Income) decreases in most developed countries and income gaps increase (IMF 2007), the success story of the main globalization paradigm gets legitimacy, because this development is often compensated by cheaper imports from lowand middle-income countries. In an article Class in the 21th century (Therborn 2012, NLR 78), Göran Therborn analyses the fall of the European working class model, a model based on the success of the welfare-state and the socialist and Marxist traditional view of an ever stronger working class with trade unions and labor parties. This European model, including ILO's model of tripartite industrial relations and regulations, reached its peak in the 1970s, when the concept of the welfare-state, social equality, public sector ownership, and industrial working class' influence was exported to every corner of the world (ibid: p. 28). The intellectual and academic interest for labor issues also peaked in the 1970s. This working class European model is gone, although unions and NGO supporters mobilize massive demonstrations after the 2008 economic crisis in struggles against the IMF, EU-Commission, and ECB troika austerity policies, mainly in southern Europe. Chancellor Angela Merkel describes the neoliberal crisis policy in EU under the heading "market-conforming democracy" (Berger 2013), that is, EU democracy has to adapt to the "laws" of free global and European market competition. The main result of neoliberal globalization is a national competition of trade unions against other workers and countries both in the South and in the EU, not international solidarity, according to Therborn. Still, he mentions examples of solidarity support of unions to struggles in the South, such as the Wage floor campaign (ibid: p. 26), a movement for living wages or minimum wages.

Globalization has influenced several new theoretical positions and debates on labor, but also caused some bewilderment, within the broad field of international labor and trade union studies, criss-crossing different disciplines such as industrial relations, labor history, sociology, and geography. Although the alternative positions presented below may differ in theoretical focus and context, for example, from agency to structure, from social movement to labor-NGOs, from company level to global macro level, they all have some universal claims in common, challenging the more national institutional traditions within labor and trade union studies. However, they give a rather fragmented picture on the issue of international revitalization of labor. We try to give a broader theoretical context by relating international revitalization to reconceptualization of working class and to different paradigmatic views. Finally, we try to find some unifying elements in the fragmented picture.

The first issue discussed is the relevance of the traditional working class concept. Fewer and fewer are full-time, formally employed workers-even fewer with collective agreements. Informal sector occupations and precarious work increase in both the North and the South. One critical and alternative contribution is Guy Standing's Work after Globalization. Building Occupational Citizenship (Standing 2009). He stands for a total revision. The traditional working class with formal contracts and the whole European laborism of the past century are of no future use for international solidarity. Precarious work is growing and new institutions and social movements must be built in the interest of the precariat. The precariat is a new class being formed by globalization beneath the 
proletariat and denied occupational rights. A self-conscious precariat is a condition for revitalization of workers interest and international solidarity according to Standing.

The second issue discussed is different paradigmatic frameworks forming debates, analyses, and strategies. The mainstream globalization paradigm mentioned above has also other denotations, by critics often called "neoliberal" globalization, by Gramscioriented Marxist also called "hegemonic" globalization paradigm. Work on labor markets has to adapt to global market fluctuations as a flexible commodity in this paradigm. State and political democracy must conform to global free market competition supporting deregulation and privatization. Middle-class consumerism is the driving force in globalization. The opposite paradigmatic framework, called "counterhegemonic" or "antiliberal," is the one in which the debate on the international revitalization of labor takes place. Other theoretical schools are also critics of neoliberal globalization, like Keynesians and Regulation scholars. Politically, critics include traditional socialists, left wing social democrats, and trade unionists. Work and labor should not be treated as a flexible commodity, according to the antiliberal view. Labor rights or occupational citizenship rights must be protected and regulated by democratic decision-making. International political regulation should also set new rules for global markets with its defaults and unfair practices. However, several successful developing countries in the South neither adopt to the neoliberal agenda of Western institutions nor to the counterhegemonic view. China and East Asian countries have more state-led economies than the West. According to the Chinese paradigmatic view globalization should adapt to different sovereign countries' development path. This view is named "multicentered statism." State intervention in support of the economy is legitimate in this paradigm. It follows Asian authoritarian political tradition, but it gives little room for independent labor organization and other occupational rights. To advance fast industrialization labor is suppressed.

The third and main issue discussed is a possible revitalization of labor in a new globalization context. We will focus on the theoretical contributions in the first volumes of Global Labour Journal (GLJ 2010-2011). GLJ brings articles on emerging Asia and new perspectives on international labor solidarity. One of the main discussions dividing different views is the question if there are tendencies of a new revitalization of labor in developing countries due to neoliberal globalization and the growth of wage labor in the emerging economies in the South. Another revitalization question relates to the importance of new strategies and collective actions of labor, trade unions, and labor-NGOs in social movements and civil society in the South. Both questions divide the global labor discussion in more optimistic versus more pessimistic views regarding global revitalization and international solidarity. Most views are critical of established theories on labor. The more optimistic views tend to downplay structural changes and institutional power shifts during more than 30 years of global neoliberalism to the disadvantage of labor. The more pessimistic views tend to downplay the defensive struggle by trade unions and workers against neoliberal globalization of markets, and labor's role as often the strongest collective action force in social movements.

\section{Working class or precariat?}

Marcel van der Linden writes in his book Workers of the World. Essays toward a Global Labor History (Linden 2008) that a revision of the concept of labor is necessary due 
to globalization: "I want to contribute to a Global Labor History freed from Eurocentrism and methodological nationalism” (ibid: 9). Marx' definition of wage-workers who dispose of their own labor power as their own "fictitious" commodity on the capitalist market is too narrow, excluding many marginalized groups of workers, especially in the South. Marx' concept contains only one main road in which capitalism transforms labor power into a commodity and labor to a working class. Other forms of labor commodification, like contract labor, informal sector workers, self-employed, or chattel slavery, can actually be more profitable (producing more surplus value) to capital according to Linden. Therefore, he argues, that the orthodox working class definition based only on free wage-workers will in a global context exclude too many working groups. In many developing countries, the informal sector labor is the majority of the total labor force and many are self-employed or contracted without bargaining power. Due to privatization of the public sector and state-owned companies this sector has increased, for instance in India, reducing formal labor to a small minority. Linden's conclusion in "Who are the workers?" (ibid, chapter 2) is therefore that the working class should be redefined and be broader, including informal workers, self-employed, and indented labor. Without going into a discussion, if Linden is fair in criticizing Marx' concept of labor we agree that a reconceptualizing of the orthodox or traditional view of working class is needed.

Such a broader reconceptualizing of labor and working class is part of Frederico Deyo's theories of new forms of decommodification of labor in the globalized economy (Deyo 2004). Deyo has since long analyzed competition-driven labor systems and labor market reforms in Thailand and East Asia (Deyo 2001). Many global cost-cutting, subcontracting, and flexibility reforms, especially in labor-intensive industries, result in transfer of social reproduction cost from the employer to families who end up subsidizing labor market participation. This is kind of broad-scale decommodification of labor, because the full value of reproduction is not covered by the salary as in the orthodox wage-worker view. Deyo concludes that the institutional labor market transformation underlying neoliberal globalization in many Asian countries results in “...a progressive externalization of the cost of the social reproduction of labor from employers and states to individuals, families and communities." (Deyo 2004: 100). Furthermore, labor market deregulation undercuts social security of workers as employers are freed from statemandated (law-based) social insurance obligation such as pension, sick pay, Medicare, unemployment benefits, etc. To avoid market risks, production can be subcontracted to the informal sector and the burden of social reproduction costs put on families, causing poverty and social disorder. Upgrading of human resources, skills, and competences in more advanced sectors can also be affected negatively, because of downward competitive pressure according to Deyo (2004: 100-104). The use of decommodification of labor to cut cost and decrease labor value is not limited to developing countries. Deregulation of labor markets increases informal sector jobs on a global scale. In this context, decommodification works backward for labor and socioeconomic development.

\section{A new class-the precariat?}

Guy Standing is in line with part of Linden's and Deyo's arguing. Working class, work, and commodification need to be reconceptualized. Standing's books Work after Globalization (2009), and the less academic version The Precariat. The New Dangerous Class 
(2011) are theoretically and empirically a comprehensive critical analysis and conclusion of work during decades of neoliberal globalization. Standing takes inspiration from Polanyi's Great Transformation (1944) and agrees with the need for socially embedding the destructive capitalist markets (Standing 2009: 240). Polanyi argues theoretically for decommodification as the logical future outcome due to the need for a growing public sector and for embedded capitalist markets. Pressure would come from civil society to stabilize crisis-ridden capitalist market by public sector decommodification. In The Three Words of Welfare Capitalism, Gösta Esping-Andersen follows Polanyi's arguments and describes decommodification of labor (reproduction) as situations when services are rendered as rights and persons can sustain their livelihood without reliance on the market (Esping-Andersen 1990: 22). Polanyi and Esping-Andersen see growing decommodification as a progress, giving labor more job security and democratic rights by the welfarestate model. Standing finds Polanyi's view of the future too optimistic and points critically to the "Second Great Transformation," which he describes as the neoliberal countermovement and end of the welfare-state capitalism (2009: chapter 4). Polanyi could of course not foresee this development in 1944. The industrial working class, trade unions, and social democracy had a progressive era of laborism and decommodification, building occupational citizenship and safety rules. This era brought increased labor market regulation, in line with ILO's principle idea that "labour is not a commodity" (Kaufman 2004, 2008). The industrial citizenship includes rights and safety rules regarding seven areas: labor market conditions, employment, occupational safety, work environment, work competence, income, and collective representation (unions) (Standing 2011: 10). However, this era is gone and a new class, the precariat, emerges without occupational citizenship or any of the mentioned safety rules at work. The precariat is formed by global competition, inequality, and recommodification in a new global class structure as one of seven classes. In order from top to bottom, these classes are: the global elite, the salariat (civil servants and private high-paid employees), the proficians (technicians and professionals), the core workers (a withering working class), the precariat, the unemployed, and the detached (modern "lumpenproletariat") (Standing 2009: chapter 4).

More and more workers lose full-time jobs and end in the precariat, as part-timers, "recycling" workers, etc. due to competitive global pressure. Global migration forms the largest part of a socially fragmented precariat. They are "denizens," that is, without full national citizenship and without occupational rights. Regarding occupational rights, the whole precariat is denizens. Precariat combines the two words precarious and proletariat. However, Standing makes no distinction between the concepts precarious work and vulnerable work. The first relates to type (or lack) of work contract, the second to type (or lack) of health and safety work environment. Precarious flexible or part-time work does not have to be vulnerable, denied occupational safety rules. Full-time unionized work can be very vulnerable (Sargeant and Ori 2013: ix-xiv). There is a general agreement on the increase of precarious work globally, in both the North and South. Arne Kalleberg analyses the increase of "bad jobs" in the US and the deterioration of the quality of jobs and the employment system since the 1970s (Kalleberg 2011).

Standing builds his vision of occupational citizenship for the precariat on a new global class movement of the precarious workers, with new type of collective work associations and institutions. He makes a distinction between work (including free time and home activity) and labor (only wage earning work) to distinguish the precariat (having all types of precarious work) from the proletariat (living on wage labor). He 
does not see the possibility for an alliance with traditional trade unions or the democratic majority (or ILO). In contrast to Polanyi and ILO principles, he believes labor by definition is a commodity. Full market pressure or commodification should actually be applied on income of the salariat, the proficians, and core workers (classes enjoying special benefits and bonuses). This should help to harmonize income levels according to Standing. However, it seems to be in contrast to building occupational citizenship for the precariat, which needs decommodified (public) education and economic rights, limiting the destructive influence of the market. Especially his suggestion to institute a Basic Income to all, enabling free use of time, is obviously against commodification (2009: chapter 10, 2011: chapter 7). Furthermore, if the precariat wins its struggle for occupational citizenship, it will, by Standing's own definition, become part of the working class, not much different from the situation when working women once became part of trade unions and the labor movement. The books do not give any answer to questions of how to unite the fragmented precariat to a class with common interests, or how to build strategic alliances, except for Standing's participation and strategy in the Basic Income Earth Network. Other authors' theoretical concepts on agency and strategies build on inclusion of traditional unions or core workers in network alliances (Gereffi 2005). Peter Wad's article "Solidarity Action in Global Labor Network" published in this special issue of NJWLS represents one example. Bernt Schiller's article "The Global Challenge of Human Rights and Social Responsibility," also in this issue, represents another.

We believe the abovementioned type of theoretical focus regarding class, occupational citizenship, precarious work, labor system, commodification, and decommodification is very important, not only for global labor studies but also for social and development research in general. Regarding class and labor system the important question is not only if low status precarious workers should be included or excluded from the proletariat or working class, but also if knowledge workers and more high-educated workers should be included or excluded. We believe knowledge workers are important in international revitalization of labor, not least in trade union and labor-NGO network alliances and international solidarity campaigns.

\section{Knowledge workers. A new skill capture?}

Mass production in higher education, $\mathrm{R} \& \mathrm{D}$, and human resource management (HRM) is most important in international competition and so is the role of knowledge workers in information or network societies. Information technology takes globalization and division of labor to a new level, regarding both outsourcing and reintegration (sourcing back) of production processes (e.g., 3D printing technology).

Several writers describe the growth of knowledge in network societies (Carnoy and Castells 2001; Frenkel et al. 1999). The division of manual and intellectual labor is part of the labor process. As more and more workers continuously upgrade skills and become re-educated, the total labor force will be more knowledge based, at least in developed economies. Knowledge and information technology will be part of most work processes. New hierarchies of knowledge workers increase salary gaps, and push many academics and high educated into precarious work conditions. With mass education, several graduates end in part-time or low qualified jobs, if not in mass unemployment as in many countries in the current crisis. Consequently, knowledge workers are 
fragmented as a social and occupational category, spread over most job sectors and from the elite and middle class to the working class and beneath. Networks and knowledge work make the working class concept more complicated, but also these workers more integrated with other job categories and classes. Some groups, traditionally not seen as working class or radical unionist, such as public sector teachers, social workers, and nurses, have become involved in more militant union activity.

The role of knowledge workers is as relevant in the North as in the South. Many middle-income countries, especially in Asia, transform to knowledge-based societiesoften in a much faster speed than in the West. In elite-led Asian meritocracies, education is the first priority. China alone has more engineers than all OECD countries. India is not far behind. However, only 10-25 per cent of engineers in the two countries are considered employable or competitive on the global labor market (EngineeringUK 2012).

According to several authors, knowledge-intensive societies have changed conditions for business competition and management (Yuan Lu et al. 2008). However, more important for our discussion here: to what extent has labor and employment relation changed? Labor is supposed to own its skills as the most important element of labor power. The central question discussed here is how skills and knowledge are produced and used, including issues of control, ownership, and governance of labor skills and knowledge work generally.

Management-labor relations in knowledge-based work have generally been more individualized, self-governed, borderless (in time and location) than in labor-intensive production (Fleming and Søborg 2003; Edwards and Kuruvilla 2005; Frenkel et al. 1999). Knowledge workers have an advantage being more empowered, but the power over the skill formation process depends on how training and education is taking place in different knowledge-intensive companies and environments. Collective networking in flexible teams is also important. However, finally management in global-led firms may indirectly control skill formation, R\&D, and HRM by governance tools such as standardized or individualized performance evaluation and ranking of employees in the company. More direct control of knowledge workers, especially in private corporations and in situation of educational investments, usually take the form of signing an employment bond, a contract binding the worker for a certain period. This is a measure not to lose knowledge workers to competitors. Another more direct tool in the private sector is contracts on confidentiality of information. Because of front-line global competition in knowledge work, private companies are very restrictive and secretive about their data and information.

Public sector knowledge workers have most often a larger freedom to use information. Shared new information in the public sector is valued as a public good, as saving costs, but in the private sector often seen as a threat to ownership and competitive position. Of course, private-owned media and the whole network communication industry live on selling shared information. Still private owners' selection of information policy and knowledge workers is part of governance tools.

According to one theory, a new global skill regime has emerged and a "skill capture" by TNCs has shifted the power over firm-specific skill formation and reward systems (Lauder et al. 2008). In the knowledge-economy company management increases investment in R\&D, in HRM and skill upgrading. Education may even be their largest investment. Therefore, their interest to control, form, or govern skill formation is growing. Generally, global knowledge commodification has increased, including higher 
private education, which has become a global multibillion dollar private business in both the North and South. Commoditized education is less open, free, and research based. Other theories point to different types of skill formation system on national, industry, or company level as most important for varieties of welfare system and social protection, as well as labor market relations (Estevez-Abe et al. 2001). For instance, free public education in Nordic countries may influence the view and role of the public sector.

What are the consequences of a possible shift in the governance of skill formation for labor and employment relations? Applying theories of skill formation and knowledge commodification to revitalization of labor, a private business skill capture is a serious barrier, removing the power of knowledge from labor and democratic public control. In countries with stronger public education institutions and a tradition of democratic influence, the barrier to revitalization may be weaker. However, private global corporations will try to use the same governance tools to control skill formation and knowledge production worldwide.

In a revitalization perspective, labor's democratic recapture of skill formation and knowledge production is most important. Corporate commodification of education, media information, and $\mathrm{R} \& \mathrm{D}$ is increasing on a global scale. Intellectual property rights are a growing private business, so is securitization of data and information. Complementary public research and more open access to private research data are necessary means to revitalize and empower independent knowledge workers and recapture freedom of information.

On different dimensions of reconceptualization of work and working class, like informal sector, commodification, decommodification, knowledge work, and precarious work, we have found the traditional working class concept challenged. There is not much unity regarding which workers should be included when it comes to revitalization of labor and international solidarity.

\section{Work and labor power in different paradigms}

Global Labour Journal has in its first volume (GLJ 2010) brought contributions on labor conditions in India and China in a theoretical globalization context. Paul Bowles (2010: 12-31) presents three different theoretical paradigms and understandings of the contested field of globalization's impact on labor and workers' responses worldwide (Kuruvilla 2003, Kuruvilla et al. 2002). We will use the three paradigms to discuss difference to the question of revitalization of labor and international solidarity. Chinese and Indian labor are analyzed within the following three paradigms by Bowles: neoliberalism, antineoliberalism, and multicentered statism. However, the paradigms can be applied more broadly, as we will try to do. We will especially focus on multicentered statism as the most interesting in Bowles' view.

The neoliberal view on labor is well known. As mentioned above, labor must be flexible, commoditized, and competitive, wages must be market set, adapting to the free move of trade and investment in open markets. Labor markets should be deregulated, which also has been the case in India and China by large-scale privatization. Indian and Chinese workers will be richer, due to increased demand on their labor, not because of rights or power of labor. Western workers get cheaper products, in a win-win situation. Occupational citizenship is not accepted as a right for workers. 
The success of the neoliberal paradigm builds on the economic growth and expansion of middle classes in the South, especially in Southeast Asia and China. China is taken as proof for job growth by privatization and foreign multinational investments (World Bank 2013: 8, Figure 3). The World Bank and the Asian Development Bank (ADB) represent this view. In much of World Bank and ADB reporting, the working class is eliminated as a category. The middle-class definition is based on income and consumption levels-not on social structure or interest. The only dividing class line discussed is between the middle class and the poor. In 2008, nearly 1.9 billion people in Asia were considered part of the developing world's middle class, based on a definition of per capita consumption of 2-20 dollars a day (i.e., figures in purchasing power, PPP \$) (Chun 2010, ADB Working Paper). Many of these middle-class consumers are in the low range of the scale from 2 to 4 dollars per day and are on the verge to slipping back to poverty. Viewed from a Western middle-class perspective, people living below10 dollars a day would clearly not be considered middle class in most developed countries. They would be living below the US poverty line, which was about 13 dollars a day in 2005 (Ravillion 2009). ADB's paper argues that a rich country's poverty line cannot define a developing country's middle class. The Bank therefore proposes that a definition should depend on the purpose at hand, as there is no single universally accepted definition of what constitutes a middle class (Chun 2010). We do not agree with ADB's definition. It is based on a consumption category, "a dream-come-true" statistical picture, not on a class interest definition. However, as in many other countries, people are often happy to be identified as middle class, giving them higher status.

The second globalization paradigm is the antiliberal or counterhegemonic globalization paradigm in favor of increased global regulation of labor markets and implementation of labor rights, that is, the direct opposite of the neoliberal paradigm. It is also used as the basis for the revitalization thesis. The neoliberal denial of labor market regulation and occupational citizenship, especially in the South, could be a motivating factor for revitalization of labor, according to some theories (see Evans below). Marxist-, socialist-, Polanyi-, and Keynes-oriented views are included in the antiliberal paradigm. Different ILO conventions for labor rights, initiatives for fair labor standards, and regulation in the South via WTO or UN's Global Compact have so far had little success and mainly resulted in voluntary corporate codes of conduct, not binding global regulation.

Bowles' third paradigm multicentered statism is especially interesting because it is to some extent also China's official position. According to this theoretical position, globalization is driven by many centers and the state is not sidestepped, but an active agent. Contrary to the neoliberal position and the "Washington consensus" view in the West, sovereign states are the drivers in the globalization process, according to the socalled "Beijing consensus" model. Emerging developmental states like China, Brazil, and India have their own globalization agenda. Training of high-level state cadres and use of Sovereign Wealth Fund have helped both Singapore and China in global investment strategies. The consequence of this perspective of multicentered statism is that the state ultimately can be held accountable for labor market regulation, wages, and management-labor relations, including a larger responsibility when investing in host countries. In our interpretation, this paradigm opens up for a combined broader struggle for occupational rights and democratic citizenship rights with the state as the main target in the South. The reason is that only the state, by legislation and regulation, could eliminate precarious and vulnerable work and, only democratic transformation of the state-in 
broad alliance with middle classes, as in last century Europe-could implement occupational rights of workers. However, in reality, the Chinese state denies its own migrant workers from the countryside several civic and occupational rights by upholding the bukou system, a registration system of original residence that binds and limits labor rights to hukou registration. The labor market system has started to change slowly. In the last decade, there have been rather large local improvements in workers' situation and increases in local sector collective agreements (World Bank 2013: 266).

According to Bowles, India pays very little attention to labor issues after privatization reforms started in the 1980s. Deregulation has led to massive reductions in public sector employment and, as a consequence, in the formally employed workforce. Informal sector work has no occupational rights. Poverty is still politically important in India, labor issues are not.

\section{The revitalization debate}

\section{A positive view on revitalization of labor}

The book Grounding Globalization: Labour in the Age of Insecurity by Edward Webster et al. (2008) has caused an intensive theoretical debate in Global Labour Journal (2010), because of its claim of a possible international revitalization of labor. Webster et al. analyze everyday life of workers, their households and communities in white goods industries (large household appliances) in three countries and continents, affected by a harder and more unregulated global competition-workplaces in South Africa, Changwon in South Korea, and Electrolux at Orange in Australia. The number of large white goods producers (i.e., companies controlling $80 \%$ of the market in Europe) has gone down from 350 in 1982 to 15 in the mid-1990s (Webster et al. 2008: 38). The global hypercompetition leads to a return to "market despotism" in all three workplaces, according to Webster et al. They find similarities in workplaces, but differences in households and communities, and also in workers' strategies and reactions: retreat to the household and informal sector in South Africa (decommodification), consent to intensification in South Korea, and an experiment to globalize the struggle of Electrolux workers at Orange in Australia (ibid: Table 10.1, p. 215). The global campaign of Orange workers to link communities affected by closure with a global network of Electrolux Action Committees ended unsuccessfully, partly due to the Swedish metal workers union who had binding partnership agreement with Electrolux. Still, the authors in part III of the book, combining Marx' theory of exploitation and Polanyi's commodification theories, present a vision of a new labor internationalism formed by politically committed activists, working in decentralized networks and labor-NGOs, building new social movements, movements mainly coming from the South. Southern Initiative on Globalization and Trade Union Rights (SIGTUR) represents one such global network. We will turn back to movements in the South when discussing Evans below.

\section{A pessimistic view}

Michael Burawoy reviews the book of Webster et al. in Global Labour Journal, From Polanyi to Pollyanna: The False Optimism of Global Labour Studies (Burawoy 2010: 
301-313). The article is both an acknowledging review of the two first parts and an attack on the third rather optimistic visionary part of the book. Not long ago Burawoy himself, after the protest movement against the WTO global summit in Seattle, proposed a new social countermovement in line with his view on public and political intervention of sociology, not so far from what Webster et al. propose in Grounding Globalization. Actually, they have followed in his theoretical and strategic footsteps (as Webster points out). However, Burawoy has changed his view on labor, although his perspective is within the counterhegemonic globalization paradigm.

Which are Burawoy's arguments now to alter his position to an "uncompromising pessimism" (Burawoy 2011: 73-77)? In the review article Burawoy's arguments build on fundamental criticism of both Marx and Polanyi. The exploitation of free wageworkers is no longer the driving force of capitalist accumulation. Exploited workers in the formal sector are the privileged ones. Here, Burawoy is in line with Standing. Trade unions act mainly in accordance with local or national member interests and in local and national defensive alliances, not in global solidarity movements. He does not see the potential in international labor solidarity as suggested by Webster et al. Furthermore, manufacturing is a shrinking sector of the global economy. In line with Polanyi's "The Great Transformation" (1944), Burawoy sees commodification, not exploitation (Marx), as the driving force and threat to civilization. However, Polanyi was too optimistic about the counterforces against commodification, according to Burawoy: Neither the New Deal compromise in the US, nor the welfare-states in Europe could unite class interest to political action against the market fundamentalism of global neoliberalism since the1970s. Furthermore, Polanyi did not make a clear distinction between state and society and did not see the repressive character of the state against labor.

Burawoy presents his own theoretical perspective on labor and commodification. There are three historical waves of commodification or marketization (Burawoy 2010: 308, Figure 1: 309) each with new combinations of fictitious commodities. In the first transformation wave (1795-1914) labor commodification takes the lead, in the second wave (1914-1974) labor is less important than money, money commodification takes the lead, and, in the third wave (1974 onward) nature's commodification (land, water, and air) will ultimately take the lead over labor and money. Even knowledge is increasingly a candidate for global commodification (ibid: 310 ) as we discussed above. The struggle in the third transformation/marketization wave will be about ecological catastrophe versus a social countermovement by a multitude of civil society groups and labor against the destruction of nature. In the third wave of marketization, labor is in a defensive position more concentrating on local and national struggles than international solidarity. Here Burawoy is in line with Standing. However, contrary to Standing he does not discuss any redefinition of the working class due to globalization of work and labor. Standing has a revitalization perspective built on the struggle of the precariat as the driving force. In Burawoy's pessimistic perspective, he can neither see a global labor social movement coming in the South nor any revitalization of labor.

It would be wrong to see Burawoy's pessimistic view on revitalization of labor as exceptional. Leslie Sklair is also reconceptualizing Marxist theory, writing on the sociology of the global system. Sklair explains the relative weakness of labor and transnational labor organizations by the strength and power of the hegemonic transnational capitalist class (TCC). Capitalism has reached a new qualitative level with globalization, based on technology, productivity, and communication (Sklair 2002). Transnational corporations are core organizations and drivers of globalization. Their executives form the 
economic fraction of TCC together with leaders of global organizations like IMF, WB, and World Economic Forum. Interstate bureaucrats and politicians form the state fraction, global professionals the technical fraction, and media and advertising corporations and merchants the consumer-ideology fraction of TCC. The everyday power and practice of these fractions make possibilities for labor alternatives bleak, especially as the culture-ideology of consumerism now penetrates the whole world (Sklair 2012). Culture and ideology is commercial and commoditized. Global capitalism makes an abovesubsistence package of material possessions and services possible to almost everyone in the First World and to privileged and middle- income groups elsewhere, according to Sklair. Shopping malls are universal. The global system integrates all classes, including labor, by the culture-ideology of consumerism. However, instability threatens the system-insecurity and polarization between rich and poor classes and ecological unsustainability. Although Sklair's theory focuses on the transnational capitalist class and culture, not on labor, his conclusion on the ecological crisis is close to Burawoy's view.

\section{An optimistic view on revitalization}

In another GLJ article, Peter Evans tries to change the agenda of global labor with somewhat provoking arguments: Is it Labour's Turn to Globalize? Twenty-first Century Opportunities and Strategic Responses (Evans 2010: 352-379). Evans writes that labor normally is seen as necessarily weak on the global level due to competition, offshoring, outsourcing, and subcontracting. Nevertheless, it may be possible to see counterhegemonic forces uniting new global NGO-labor networks and alliances because of stronger opposition to neoliberal labor market deregulation and threats-to turn the argument of globalization as labor's nemesis on its head, according to Evans. Evans points to several changes in this direction:

- Economic "whipsawing" of labor because outsourcing is no longer so effective. At least runaway shops in manufacturing industries are less important, because there are fewer jobs in manufacturing. Most jobs are place-bound in services. The market for service jobs like house cleaners, nurses, public utility employment is mainly on a local or national market.

- Although there are cultural divisions and a strong individualization in the global culture, universal human rights and labor rights are now much stronger on a global level.

- Political weakness of labor in relation to the state can be a barrier-but state support has never been important for labor, unless labor has fought for it. Social movement and NGO alliances are of better use in a countermovement.

- Evans sees a promising merger of transnational unions since the cold war splits: the new International Trade Union Confederation in 2006 (ITUC), and New Global Union Federations (GUFs) for different branches. However, bargaining on the global level is almost nonexistent. The set-up of a few International Framework Agreements is weak, he admits, but a positive trend.

- New NGO-labor networks are the most important. They have a rhizome-like network structure when organizing compared to tree-like bureaucratic organization of trade unions. However, the combination of these two networks could be strong. 
- The new ease of communication with IT and social media is a gift for labor and other transnational movements.

- Most important are labor alliances with strong social movement unions in the South such as the Rio Tinto Global Union Network, SIGTUR, Latin American Network for Multinational Company Research, etc.

Evans' arguments are mainly on the agency level within the counterhegemonic paradigm, in line with Webster and coauthors. He does not relate his analysis to any change in class structure, like Standing, or specific changes in exploitation and labor system, like Deyo, or difference in social or state setting, like Bowles' multicentered statism.

\section{False optimism?}

Burawoy criticizes Evans for false optimism (Burawoy 2010, 2011). Recognizing Evans' lifelong work on Polanyi and the development-state, Buroway thinks it is wrong of him to ignore the state in organizing counterstruggles, because the state confines these to the national arena. Evan insists that the Polanyi-type countermovement to market expansion must take place on a global scale (although not thought of by Polanyi), because capitalism is now globally organized. Burawoy cannot see any stronger tendencies to organize labor globally: the local or national struggles are not connected to the global in his view. The result of Evans' theories “... is a 'counter-hegemonic' globalization which clutches at straws" (Burawoy 2010: 302).

Burawoy also brings in other "optimistic" contributions, which, like Evans, do not make the necessary distinction between the Marxist type of exploitation and the Polanyi type of commodification. Beverly Silver analyses workers' movement and globalization since 1870 in her Forces of Labor (Silver 2003), but according to Burawoy, without this theoretical precision. In her view capitalist development moves between crises of legitimation and crises of profitability. Furthermore "She assumes that labor is always interested in resisting exploitation and its success depends on its capacity, that is the mobilization of two types of resources—structural and associational power" (Burawoy 2010: 303), resources, which in her view make a revitalization possible. Silver's historical view on labor's interest and potential actions is shared by many other scholars within the field of global labor studies, making Burawoy's criticism no less important.

\section{Comparison of views}

If we compare the optimistic and pessimistic views of labor revitalization, they are contradictory at least in the provocative way they are formulated for the sake of their arguments. In addition, Standing's view, revitalization of the precariat, is in sharp contradiction to that of the others. However, all three views are within the counterhegemonic globalization paradigm. Therefore, we want to see if there could be some unifying elements. If we look at each view as a suggestion of a possible road of struggle, all three roads, the one of the precariat (Standing), the other of blue- and white-collar trade unions in NGO network alliances (Webster et al. and Evans), and the third of NGOs for ecological survival (Burawoy), need some preconditions. One road of struggle is a precondition for the other! 
The theoretical arguments for our complementary view—going beyond the single author's own writing and combining them-are simple ones: Precarious informal sector workers need the support of traditional working class to get occupational rights. The traditional working class needs the success of informal workers not to get their rights downgraded. Ecological global transformation needs knowledge workers and all workers' support. However, this support will only come if a vision of future work seems to be more safe, secure, and sustainable. To support occupational rights of precarious or vulnerable workers (or the precariat in Standing's view) is rather natural from a labor interest or counterhegemonic point of view. To support global labor-NGO and international trade union alliances, as Evans and Webster et al. suggest, is also very natural in a counterhegemonic perspective. To support ecological struggles for sustainable future livelihoods and decommodification of natural resources falls naturally in the long-term interest of everybody. To connect and unite the different struggles in a broader counterhegemonic movement we believe labor-NGO knowledge workers are essential.

One example of a successful united struggle is the Accord on Fire and Building Safety in Bangladesh concluded in May 2013 by IndustriALL, UNIGlobal, Bangladesh unions, international garment brands and retailers, and International NGOs, including Clean Clothes Campaign and Workers Rights Consortium (www.cleanclothes.org www. workersrights.org). The background was the factory disaster at Rana Plaza this spring and a series of lethal accidents in the garment industry before. A legally binding international regulation implemented by a Steering Committee with equal representation in the Bangladesh garment industry is a breakthrough in international industrial relations.

\section{Conclusion}

The concept of labor and working class interest has had a defining role for Western societies, for social and intellectual consciousness. The working class developed into an independent social force. Especially in Europe, labor had a major role in defining social movements, solidarity, reform or revolution, democracy, universal rights, equality, political left and right, welfare systems, etc. Labor has been integrated in historical and social analyses. For almost a century labor problems were seen as a major threat to economic growth and political stability in the West, which made labor's success project of welfare and employment reforms possible. As means of conflict resolution labor was incorporated in industrial relations systems and the ILO tripartite system, which still stands as a model for international labor and human rights conventions and standards.

In contrast, Asian development models are identified with the new rise of middle classes and meritocracy or elite governance. Mass education is prioritized. Education will take you to higher social status, as emphasized in public discourse. In a development-state strategy of fast industrialization and modernization, labor is subordinated and occupational rights suppressed. The social issue of labor is most often eliminated from public or political agenda (Chan 2001). The working class is no longer seen as an independent force or a threat to development, although Asia now has the majority of the working class of the world and China the largest proletariat. Ironically, the official ideology of the Chinese communist party is based on proletarian leadership. Third world anticolonial liberalization was inspired by socialist and communist ideas, in Asia especially by the Chinese revolution. Ironically again, trade unions and labor had often a 
more recognized status and influence in this early period when the working class hardly existed, than now, when industrial mass production has moved to Asia.

The theoretical contributions illuminating the question of revitalization of labor have shown a rather fragmented picture. We have pointed to the need for a revision or reconceptualization of the working class concept, including or excluding precarious workers and knowledge workers. We raised the question of privatization of knowledge work, new governance measures, and a skill capture by private corporation, underlining the need for public and labor recapture of knowledge and skill development. In our analysis, the optimistic view on international revitalization of labor, represented by Evans and Webster et al., is confronted by a pessimistic view, represented by Burawoy. Standing's view of the need to revitalize the global precariat as a new class of workers comes in conflict with traditional trade union and core workers interest. To make justice to the different conflicting views we use the counterhegemonic paradigm of globalization to show the possibility to unite the different strands around a common struggle for sustainable conditions in working life and an ecological friendly environment.

\section{References}

Berger, J. (2013) Market-conforming Democracy. Newswire article. Portland Independent Media Center 11/8/2013.

Bowles, P. (2010) “Globalization's Problematic for Labour: Three Paradigms”. Global Labour Journal. Vol. 1, No 1 (12-31).

Burawoy, M. (2010) "From Polanyi to Pollyanna: The False Optimism of Global Labour Studies”. Global Labour Journal. Vol. 1, No 2 (301-313).

Burawoy, M. (2011) “On Uncompromising Pessimism: Response to my Critics”. Global Labour Journal. Vol. 2, No 1 (73-77).

Carnoy, M. and Castells, M (2001) Globalization, the Knowledge Society, and the Network State: Poulantzas at the Millenium. Global Networks, Vol. 1, No 1 (1-18).

Chan, A. (2001) China's Workers Under Assault: The Exploitation of Labor in a Globalizing Economy, Armonk, NY: M.E. Sharpe.

Chun, N. (2010) Middle class size in the past, present, and the future: A description of trends in Asia. The Asian Development Bank Economics, Working paper series, No. 217.

Deyo, F. (2001) Economic Governance and the Challenge of Flexibility in East Asia, Lanham, MD: Rowman \& Littlefield.

Deyo, F. (2004) 'Reforming Labor, Belaboring reform: Structural Adjustment in Thailand and East Asia.' In Yoichiro Sato (ed.) Growth and Governance in Asia. Honolulu: Asia-Pacific Centre for Security Studies.

Edwards, T. \& Kuruvilla, S. (2005) "International HRM: National Business Systems, Organizational Politics and the International Division of Labour in MNCs”. International Journal of Human Resource Management. Vo. 16, No 1 (1-21).

EngineeringUK (2012) The skills 'threat' from China and India-Fact or fiction. Report of key findings. Internet.

Esping-Andersen, G. (1990) The Three Worlds of Welfare Capitalism. Princeton, NJ: Princeton University Press.

Estevez-Abe, M., Iversen, T. \& Soskiece, D. (2001) 'Social Protection and the Formation of Skills: A Reinterpretation of the Welfare State', in Peter A. Hall \& David Soskice (eds), Varieties of Capitalism: The Institutional Foundation of Comparative Advantage. Oxford: Oxford University Press. 
Evans, P. (2010) Is it Labour's Turn to Globalize? Twenty-first Century Opportunities and Strategic Responses. Global Labour Journal. Vol. 1, No 3 (352-379).

Fleming, D. \& Søborg, H,(2003) “Towards Reflexive Governance of Management-Labour Relations? Corporate Culture and Human Resource Management in Malaysia and Singapore", in Daniel Fleming \& Christer Thörnqvist (eds) Nordic Management-Labour Relations and Internationalization-Converging and Diverging Tendencies. Nordic Council of Ministers.

Frenkel, S. J., Korczynski, M., Shire, K. A., Tam, M. (1999) On the Front Line: Organization of Work In the Information Economy, Itaca, NY and London: Cornell University Press.

Gereffi, G. (2005) The new offshoring of jobs and global development, ILO Social Policy Lectures, Jamaica, December 2005, Geneva: IILS, ILO.

IMF (2007) Globalization and Income Inequality. Working Paper 07/169.

Kalleberg, A. L. (2011) Good Jobs, Bad Jobs: The Rise of Polarized and Precarious Employment Systems in the United States. 1970s to 2000s. New York, NY: Sage.

Kaufman, B. E. (2004) The global evolution of industrial relations: Events, ideas and the IIRA. International Labour Office, Geneva, 2004.

Kaufman, B. E. (2008) "Paradigms in Industrial Relations: Original, Modern and Versions in-between”. British Journal of Industrial Relations. Vol. 46, No 2 (314-339).

Kuruvilla, S. (2003) Social Dialogue for Decent Work, Discussion Paper, Geneva: IILS.

Kuruvilla, S., Das, S., Kwon, H., Kwon, S. (2002) “Trade Union Growth and Decline in Asia". British Journal of Industrial Relations. Vol. 40, No 3 (431-461).

Lauder, H., Brown, P. \& Ashton, D. (2008), "Globalisation, Skill Formation and the Varieties of Capitalism Approach". New Political Economy. Vol. 13, No. 1 (19-35).

Polanyi, K. (1944, 2001 edn) The Great Transformation. The Political and Economic Origin of Our Time. Boston: Beacon Press.

Ravillion, M. (2009). The Developing World's Bulging (but Vulnerable) "Middle Class". Policy research working paper 4816. The World Bank, Development Research Group, Director's Office.

Sargeant, M. \& Martina Ori (2013) in Vulnerable Workers and Precarious Working (eds. Tayo Fashoyin and Michele Tiraboschi). Newcastle upon Tyne: Cambridge Scholars Publishing.

Silver, B. (2003) Forces of Labor: Workers' Movements and Globalization since 1870. Cambridge: Cambridge University Press.

Sklair, L. (2002) Globalization: Capitalism and its Alternatives, $3^{\text {rd }}$ edn. Oxford: Oxford University Press.

Sklair, L. (2012) Culture-Ideology of Consumerism. The Wiley-Blackwell Encyclopedia of Globalization. Blackwell Publishing Ltd. Online version.

Standing, G. (2009) Work after Globalization. Building Occupational Citizenship. Cheltenham \& Northhampton: Edgar Elgar.

Standing, G. (2011) The Precariat. The New Dangerous Class. New York and London: Bloomsbury Academic.

Therborn, G. (2012) "Class in the $21^{\text {th }}$ century", New Left Review. 78, 5-29.

Van der Linden, M. (2008) Workers of the World. Essays toward a Global Labor History. Leiden, Boston: Brill.

Webster, E., Rob Lambert, \& Andries Bezuidenhout (2008). Grounding Globalization. Labour in the Age of Insecurity. Oxford: Blackwell.

World Bank (2013) Jobs. World Development Report.

www.cleanclothes.org/issues/faq-safety-accord/

www.workersrights.org 18 June 2013 Hensler, B. and Jeremy Blasi

Yuan Lu, Eric W. K. Tsang, \& Mike W. Peng (2008) "Knowledge Management and Innovation Strategy in the Asia Pacific: Towards an Institution-Based View", Asia Pacific Journal of Management. Vol. 25 (361-374). 